\title{
Development of tidally related behaviour of a newly settled 0-group plaice (Pleuronectes platessa) population in the western Wadden Sea
}

\author{
H. W. van der Veer \& M. J. N. Bergman \\ Netherlands Institute for Sea Research, P.O. Box 59, 1790 AB Den Burg Texel, The Netherlands
}

\begin{abstract}
The development of tidal migration in a 0-group plaice Pleuronectes platessa L. population on a tidal flat in the western Wadden Sea was studied. Immigrating plaice larvae from the North Sea tended to settle on the tidal flats usually at some distance from the edge of the tidal channel in areas where at low water a film of 2 to $8 \mathrm{~cm}$ of water remained. During the following weeks, tidal migrations developed towards the gullies and channel during ebb tide. In June, 1 mo after the arrival of the last new settlers, the complete 0-group population left the flats during ebb tide to return with the flood during both day and night. In the course of the season, the low water refuge gradually shifted from small gullies near the area of settlement to the deeper tidal channel. In contrast to the generally held view that tidal migration develops as a means to exploit rich feeding grounds present in the tidal area, the unfavourable temperature and oxygen conditions on the Balgzand from June onwards, in particular during low water, suggest that in this area tidal migration has to be considered as a forced escape behaviour of plaice from the feeding grounds. This is supported by the fact that during nighttime, when $\mathrm{O}_{2}$ deficiency is higher, plaice as a rule left the flats earlier after high water. Nevertheless, the last group of newly settled larvae may suffer under these environmental conditions, which might even result in mortality. Since abundant larval years are associated with a relatively strong settlement in April, such a mortality factor might have a density-dependent component between years.
\end{abstract}

\section{INTRODUCTION}

Previous papers on the population dynamics of 0 group plaice Pleuronectes platessa L. in the Wadden Sea show that during and shortly after settlement of pelagic larvae on a tidal flat area in spring, mortality rates are high and seem to be density-dependent (van der Veer 1985, 1986). For a study of the causes of these high mortalities, more detailed information is required on distribution patterns of newly settled plaice throughout the tidal cycle.

At the end of their first year of life, larger plaice exhibit rhythmic tidal migrations on and off the flats (Kuipers 1973), but the behaviour of 0 -group plaice just after settlement during the period of density-dependent mortality is poorly known. Previous studies (Bergman et al. 1976, 1980) suggest that larvae settle on the flats, and that tidal migration develops only a few weeks later.

This paper describes in more detail the tidal behaviour of 0 -group plaice from the first settling in
February until the end of the first year of life, during both day and night.

\section{MATERIAL AND METHODS}

All sampling was carried out within a square of about $1 \mathrm{~km}^{2}$ located in the eastern part of the Balgzand (Fig. 1), a tidal flat area in the western Wadden Sea known for its dense juvenile plaice population (Kuipers 1977, Zijlstra et al. 1982, van der Veer 1986). The experimental area is bordered in the east by the main tidal channel (Amsteldiep), in the north and south by small gullies through which during ebb tide water recedes into the main channel, and in the west by a watershed (Fig. 2). The main part of the area consists of flats, which are submerged during most of the tidal cycle. The maximum depth is 1 to $1.5 \mathrm{~m}$ water, depending on weather conditions and lunar phase. Normally, the flats are drained for 2 to $3 \mathrm{~h}$ and submerged for 9 to $10 \mathrm{~h}$ of the tidal cycle. The surface of the flat is not 


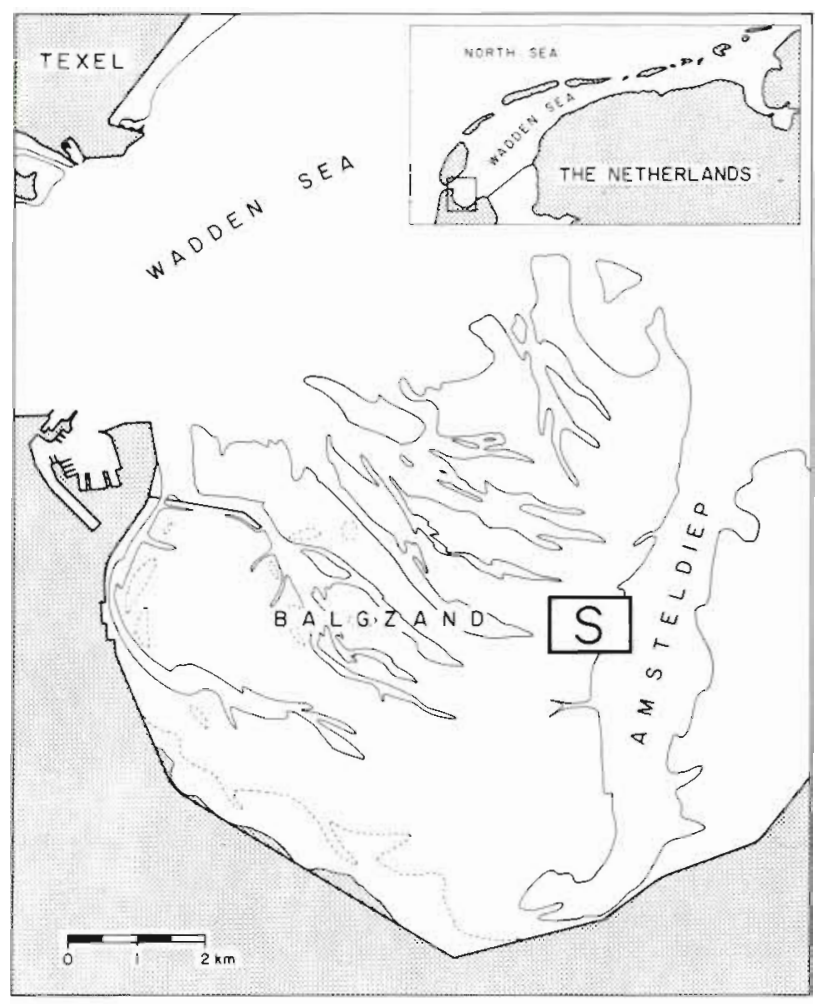

Fig. 1 Map of the Balgzand tidal flats in the western Wadden Sea, with the area of sampling (S)

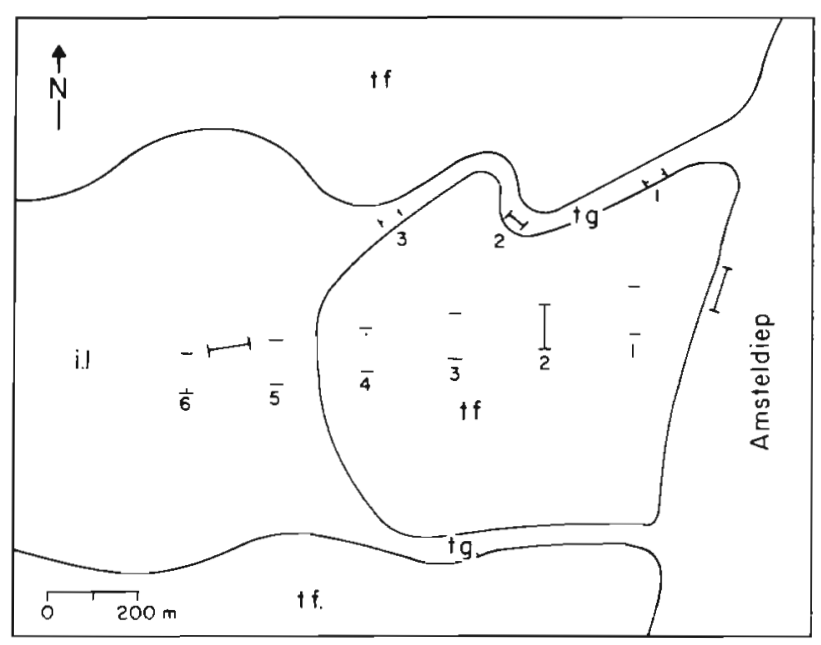

Fig. 2. Enlargement of the selected area with the sampling sites $(\longmapsto) . i .1:$ inner lake, tudal flats with a 1 to $5 \mathrm{~cm}$ waterfilm at low water, $t$ t drained tidal flat; t.g : tıdal gully; Amsteldiep tidal channel. Enlarged survey pattern at low and high water is also indicated ( 11 )

entirely draned at low water and some areas remain submerged with shallow pools of about 1 to $5 \mathrm{~cm}$ in depth, further referred to as 'inner lake' This inner lake represents a common feature of the tidal flats in the Wadden Sea. Medıan grain size of the sedıment on the flats is about $140 \mu \mathrm{m}$ and the sult content is $4 \%$
(Dapper \& van der Veer 1981). The bottom of the tidal gulles and the tidal channel consists mainly of coarse sand, but is locally very muddy.

In this area $24 \mathrm{~h}$ sampling series were taken regularly from the end of February to September in 1980; untıl the first half of June sampling was carried out weekly. Durng each series 1 sample was collected at 4 locations on every second hour: in the channel, in the gully, on the dramed flats and in the inner lake (Fig. 2). At high and low tide during daylight sampling intensity was increased to 3 samples in the gully and 6 on the flats at increasing distances from the main channel. In 1981, routıne sampling was maintained only at high and low water during daytime with a 2 wk interval from the second half of January to June.

At each station fishing was done with a $1 \mathrm{~m}$ beam trawl with 1 tickler chain. The netting was made of knotless nylon with a mesh size of $3 \times 3 \mathrm{~mm}$. The length of the towing line was $6 \mathrm{~m}$ and a towing speed of about $35 \mathrm{~m} \mathrm{~min}^{-1}$ was used, following Riley \& Corlett (1966). At water depths of less than $50 \mathrm{~cm}$ the net was pulled by hand, otherwise a rubber dinghy with a $25 \mathrm{hp}$ outboard motor was used. Each haul covered a distance of $50 \mathrm{~m}$ in the gully and of $100 \mathrm{~m}$ at the other locations. The exact distance was measured by means of a meter-wheel mounted to the frame outside the trawl.

Catches were sorted within an hour, and preserved in $70 \%$ alcohol. Within the next week all 0-group plaice were measured in $\mathrm{mm}$ size classes. No correction was made for shrinkage. Gear efficiency for the $1 \mathrm{~m}$ beam trawl has been assumed to be similar to that reported for the $2 \mathrm{~m}$ beam trawl by Kuipers (1975a). Only the effects of mesh selection were investigated by fishıng with a $3 \mathrm{~mm}$ net enclosed by a $2 \mathrm{~mm}$ net and comparing the size distribution of the numbers caught in both nets (Fig. 3). No adjustments were made for

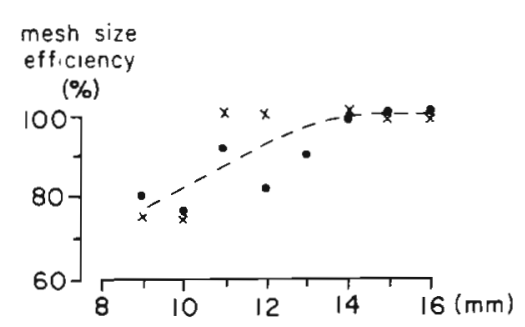

Fig 3 Mesh efficiency (\%) for the $3 \mathrm{~mm}$ net of the $1 \mathrm{~m}$ beam trawl, as estumated from a comparison of the size distribution of the plauce caught in the $3 \mathrm{~mm}$ net and those passing through the $3 \mathrm{~mm}$ net and caught by an enclosed $2 \mathrm{~mm}$ Monodur nylon net

possible differences in net efficiency when pulling by hand or from the dinghy. After correction for net efficlency, all numbers were expressed in densities per $100 \mathrm{~m}^{2}$ (ind $100 \mathrm{~m}^{-2}$ ). 
When sampling the inner lake at low tide, some physico-chemical variables of the near bottom water were measured. Temperature and salinity were determined with a type MC 5 of Electronic Switch Gear Ltd, with an accuracy of $0.1^{\circ} \mathrm{C}$ and $0.1 \% \mathrm{~S}$. Oxygen saturation was measured with a Yellow Springs Instruments Model 57 (dissolved oxygen probe 5739) and an accuracy of $3 \%$.

\section{RESULTS}

\section{Settlement}

A comparison of plaice densities at high water in 1980 and 1981 on the flats with those in the gully and the channel showed that during the period of settling from February up to the beginning of May (see van der Veer 1986) relatively low numbers were found in the subtidal zone (Fig. 4). Therefore, main settlement appeared to occur on the tidal flats, particularly in the inner lake. After the period of settling from May onwards, densities on the flats at high tide remained high compared to those in the gully and the channel, although a shift occurred from the inner lake towards the better drained flats closer to the tidal channel.

Until May the average length of the 0 -group plaice remained almost constant, which is indicative of the continuous settlement of new larvae (Fig. 5). Thereafter, mean size increased rapidly to about $60 \mathrm{~mm}$ by the end of June. No consistent differences were

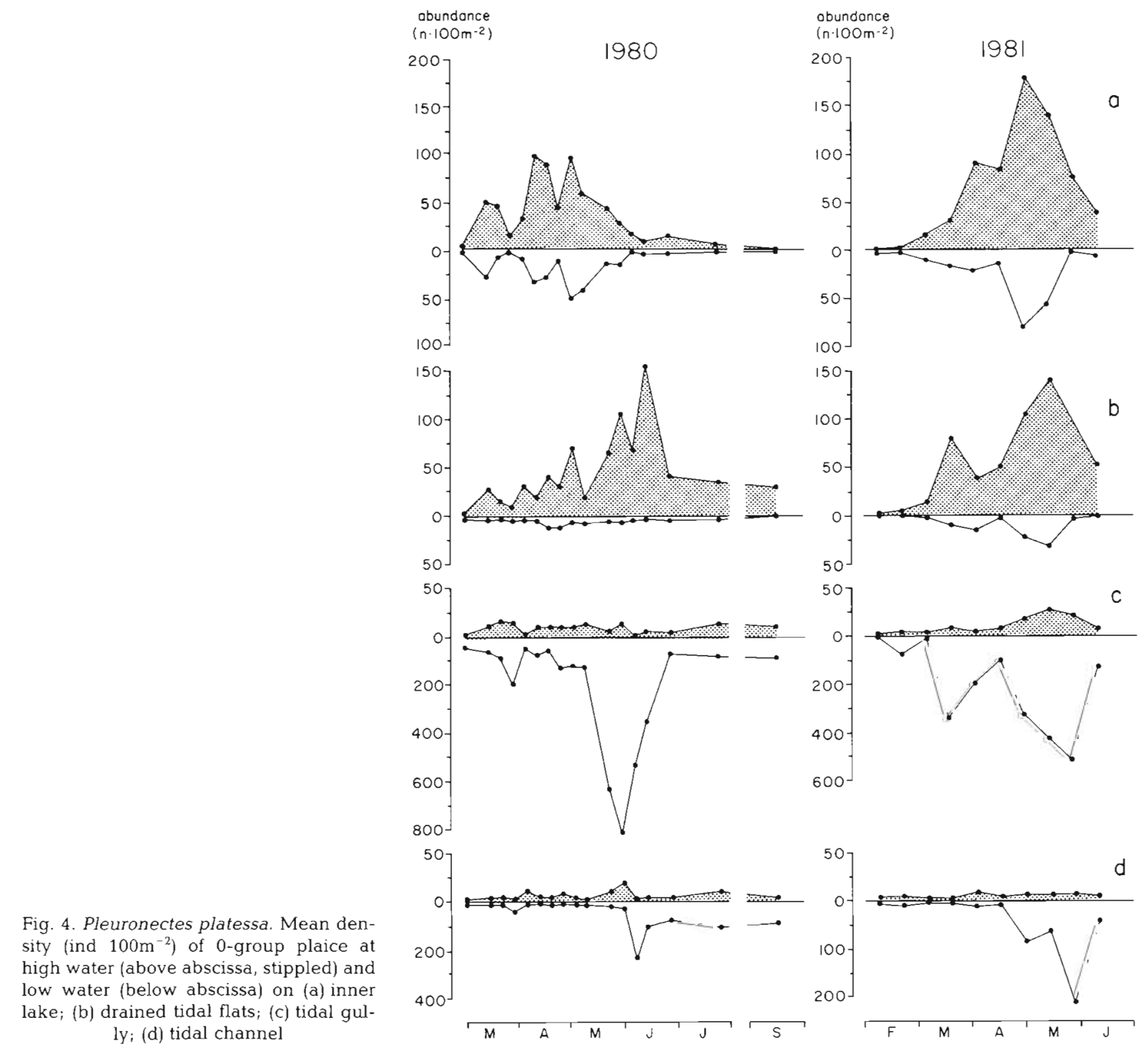


observed between areas and between high and low water with respect to length (Fig. 5).

\section{Tidal rhythmicity}

During the settling period (up to May), most 0-group plaice were found at low water in the inner lake and to a lesser extent in the tidal gully. Because of the relatively small area of the gullies, the main part of the population should be present on the tidal flats. The estimates of numbers on the inner lake, however, were lower than at high water, whereas one would expect a concentration effect. This might indicate sampling problems at low water depths when the net was pulled by hand. The increasing densities in the gully and channel at low water showed that in the course of the season a tidal migration developed. In both years the development was completed about 1 mo after the arrival of the latest settling larvae, in the middle of June, when nearly all plaice migrated from the flats with ebb tide.

Analysis of the mean size of the fish caught at the 4 locations during high and low waters revealed rather variable results. During high water no consistent pattern was observed. At low water the smallest fish were normally found in the inner lake and to a less extent on the other drained flat in both years (Fig. 5).

The intensified sampling at high and low water during daytime permitted a closer examination of the
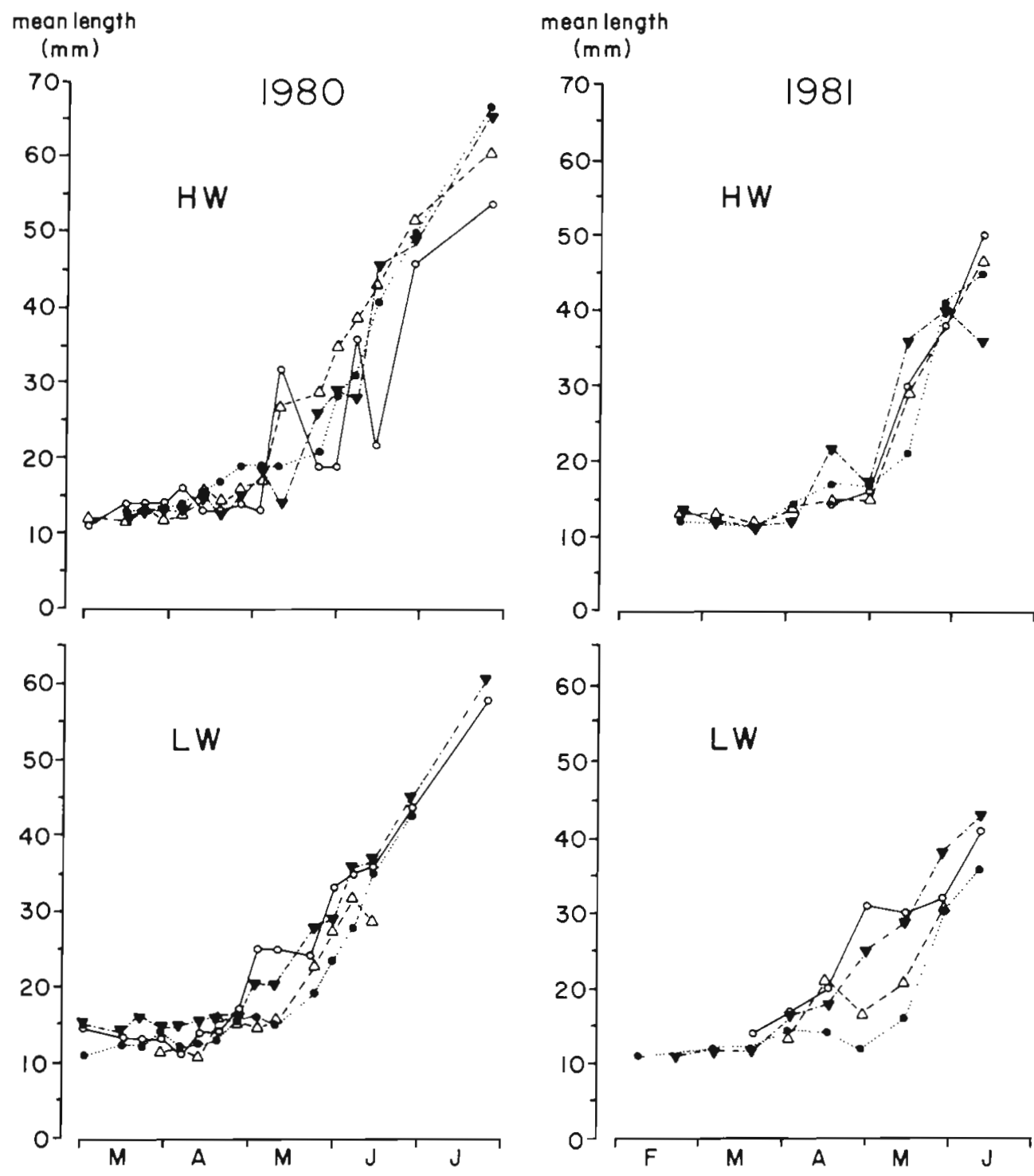

Fig. 5. Pleuronectes platessa. Mean length (mm) of 0-group plaice at high and low water in 1980 and 1981 $\left(\Delta^{-}-\Delta\right)$ drained tidal flats; $(\mathbf{\nabla} .-\nabla)$ tidal gully; $\left(0_{-}\right)$tidal channel 
abundance

$\left(n \cdot 100 m^{-2}\right)$
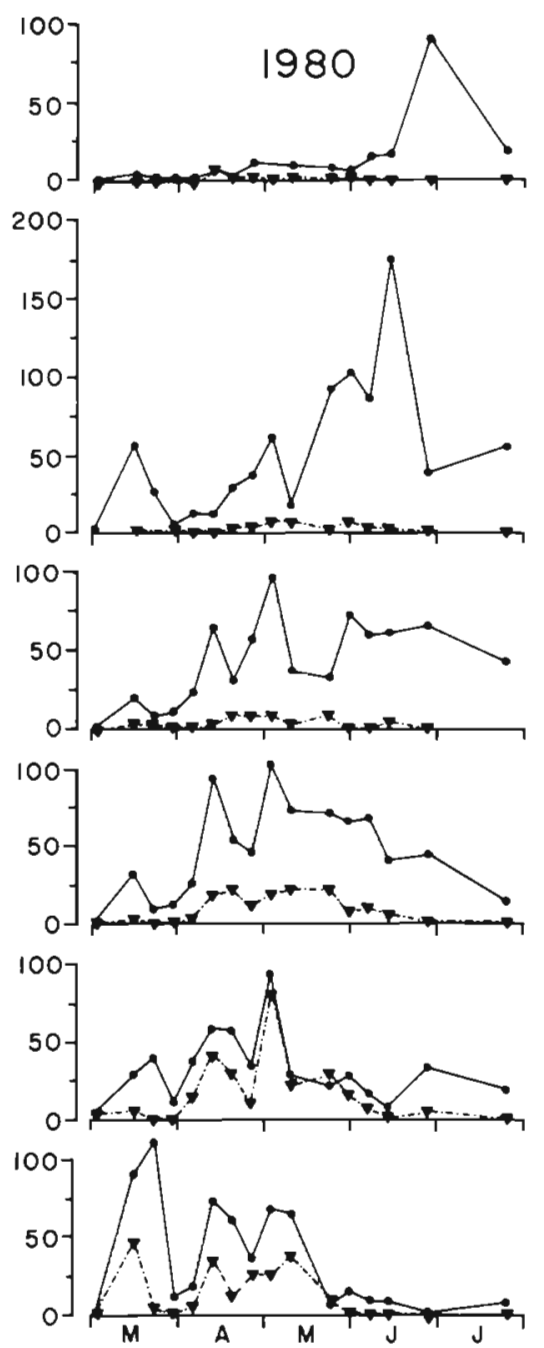

abundance
$\left(n \cdot 100 m^{-2}\right)$
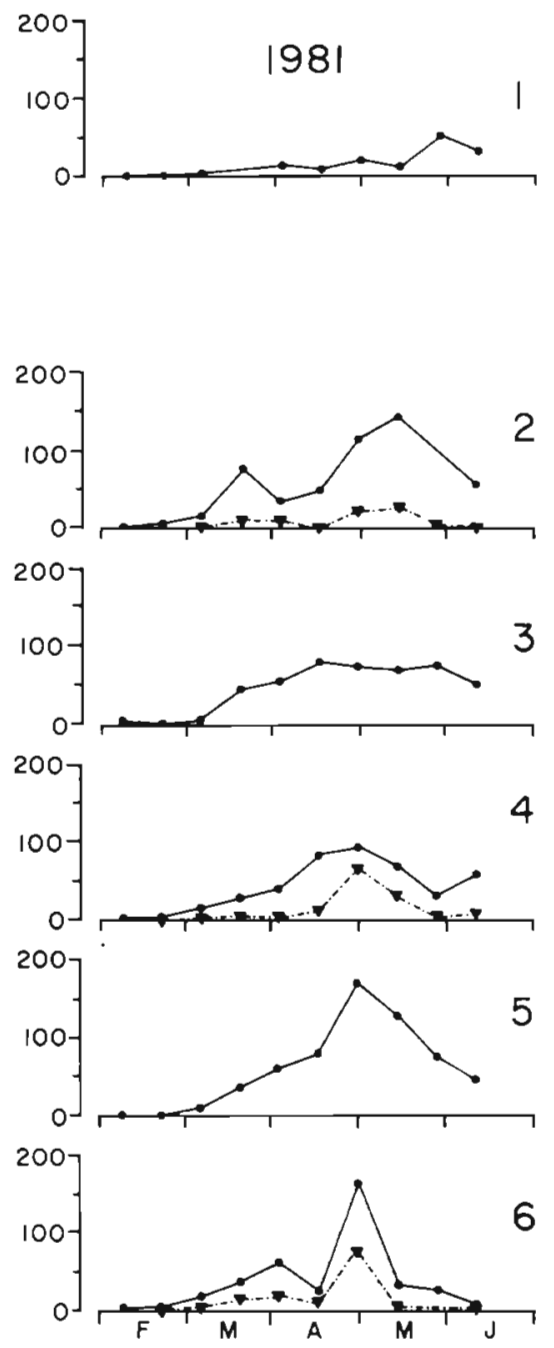

Fig. 6. Pleuronectes platessa. Mean density (ind $100 \mathrm{~m}^{-2}$ ) of 0 -group plaice at high (-) and low (-.) water on the 6 hauls on the tidal flat with increasing distance from the tidal channel in 1980 and 1981. Stns 1 to 4 : drained flats; 5 \& 6 : inner lake (see Fig. 2) migration pattern (Fig, 6). During the period of settlement until May, densities of plaice at low and high water went up with increasing distance from the channel, indicating the importance of the inner lake as a settling area. Also at high water this inner lake had the highest abundances. With the development of tidal migration, however, the maximum densities at high water shifted in both years towards the fully drained flats, closer to the channel. No consistent difference was observed between day and night.

The mechanism of tidal migration is illustrated in Fig. 7. Variations in plaice densities over a whole tidal cycle are given for the 4 main locations for a representative week in early June, when tidal migration had already well developed. Densities on the flats started to decrease very soon after high water, both during day and night-time. At low water only a few plaice remained on the inner lake. Only 1 to $2 \mathrm{~h}$ after low water plaice were already leaving the gully and channel to return onto the flats with the rising water.

\section{Oxygen, temperature and salinity conditions}

Fig. 8 shows the oxygen, temperature and salinity conditions in the inner lake for high and low water separately, both during day and night in 1980. Over the season oxygen saturation at high water fluctuated between 80 and $120 \%$ during daytime and between 40 and $90 \%$ during night-time. Lowest values were observed in June. At low water during daytime the oxygen saturation of the waterfilm of 1 to $5 \mathrm{~cm}$ ranged from $60 \%$ to as high as $180 \%$, whereas from May on the values were as low as 30 to $40 \%$ during the night. Differences between day and night saturation values tended to be highest in the summer, as a consequence 

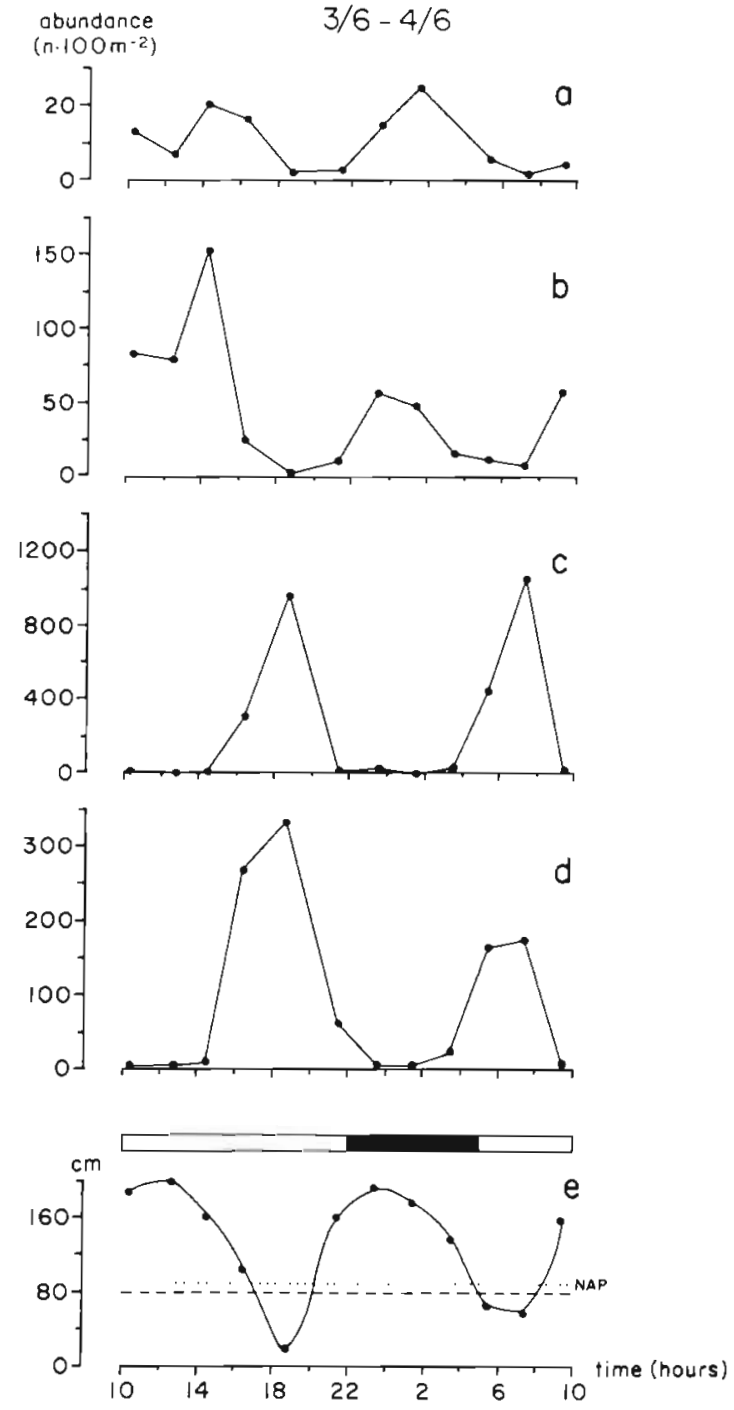

Fig. 7. Pleuronectes platessa. 0-group plaice density (ind $100 \mathrm{~m}^{-2}$ ) during a tidal cycle at (a) inner lake; (b) drained tidal flat; (c) tidal gully; (d) tidal channel. Day- ( $\square$ ) and nighttime ( $\square$ ) are indicated, together with (e) water depth in the tidal channel. (…...) Dutch reduction level (NAP); (--) level of tidal flats

of higher $\mathrm{O}_{2}$ consumption of the flora and fauna community, and of higher temperatures

Water temperature in the area increased from ca $4{ }^{\circ} \mathrm{C}$ at the beginning of the year up to $\mathrm{Ca} 20^{\circ} \mathrm{C}$ in JuneJuly. Maximum temperatures were reached at low water, when occasionally $24^{\circ} \mathrm{C}$ was recorded during daytime. The difference between day and night temperatures ranged from 2 to $3 \mathrm{C}^{\circ}$ during high water and up to $6 \mathrm{C}^{\circ}$ during low water.

From February on salinity showed an increase from about 16 to $28 \%$ followed by lower values from July on. Neither stage of the tidal cycle nor time of day affected salinity in a consistent manner.

\section{DISCUSSION}

Various fish species have developed the ability to use intertidal feeding grounds, and to do so they have to migrate onto the submerged flats with the rising tide and to withdraw into the subtidal zone during receding tide (Edwards \& Steele 1968, Tyler 1971, Gibson 1973a, b, Kuipers 1973, Wolff et al. 1981, Wirjoatmodjo \& Pitcher 1984).

For I and II group plaice tidal migration has been described in the Wadden Sea by Kuipers (1973) and in the Dutch Delta area by Wolff et al. (1981). 0-group plaice show the same behaviour during their first year of life in August-September (Gibson 1973a, b, Kuipers 1973).

Settlement on tidal flats, as described in Bergman et al. $(1976,1980)$ and in the present study resembles the situation in the German Wadden Sea (Berghahn 1983). In other areas settlement seems to occur partly (Bregnballe 1961, Macer 1967, Gibson 1973b) or totally (Lockwood 1974) subtidally, followed by an invasion of the more inshore parts later.

Directly after settlement there are no signs of a tidal migration, both on the Balgzand and in the German Wadden Sea (Berghahn 1983). At low water the small plaice remain on the flats in shallow pools. The last group of settlers in early May need about 1 mo to develop this tidal behaviour, a period similar to that observed in previous years - 1976 and 1977 - in the same area (Bergman et al. 1976, 1980) and mentioned in the German Wadden Sea (Berghahn 1983). From June onwards, the whole population migrates on and off the tidal flats with each tide in very much the same way as has been established by Kuipers (1973) for 0group plaice in September. The tidal migration pattern was present both during day and night, which agrees with the conclusions of Gibson (1973b) for British waters. In contrast to Bregnballe (1961) no differences in spatial distribution could be observed between day and night-time.

In the course of the season the distribution pattern during the various stages of the tidal cycle changes slightly. At first the fish migrate to both the gully and the channel, while after some time the main low water refuge is shifted towards the tidal channel. At high water this shift is associated with a change in the distribution pattern from the inner lake to the drained flat, located more closely to the channel.

Growth of the new settlers will vary due to temperature differences both within the period of settling and between years. Migrating plaice are always larger, as is obvious from the average sizes in the various locations during low water when migrating fish are spatially separated from the non-migrating fish.

The lack of tidal migration during the first weeks 

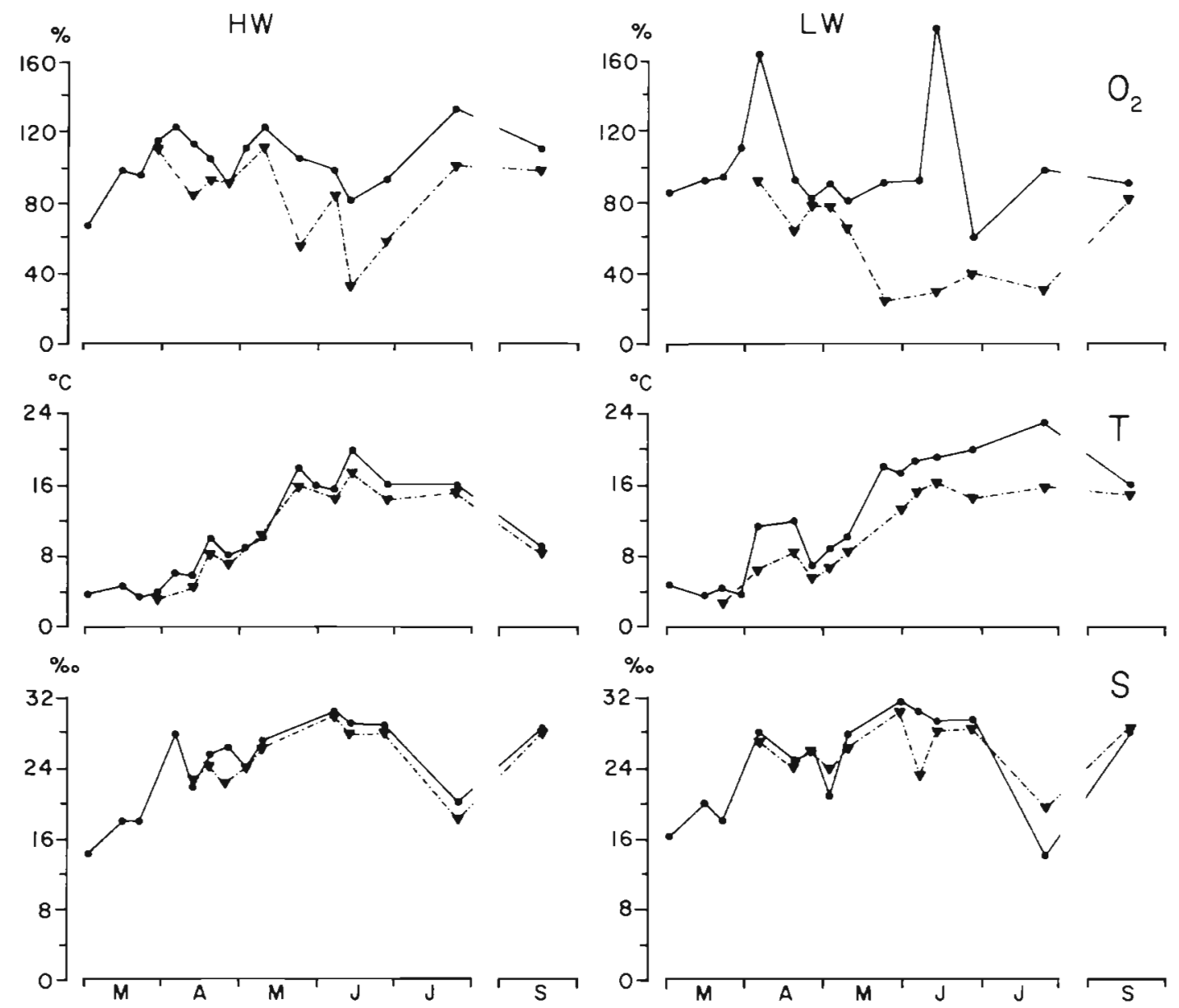

Fig. 8. Temperature $\left({ }^{\circ} \mathrm{C}\right)$ oxygen $(\%$ saturation) and salinity $(\%)$ at high and low water during $(\bullet \bullet)$ day and $(\mathbf{\nabla}-\cdot-\nabla)$ night-time at the inner lake in 1980

after settlement prevents small plaice being subject to predators living in the deeper waters of the gully and channel. As the fish grow in size, they become less vulnerable to predation and are able to move into deeper water with ebbing tide.

The factors initiating this tidal migration are unknown. Gibson (1973b, 1975) showed that the migration pattern is based on an internal rhythm. Plaice seem to develop this tidal migration apparently independently of the time of larval arrival both in the Dutch and German Wadden Sea, which suggests that learning processes are probably important. Although the general ability to respond to the tides adequately (which involves internal tidal rhythmicity, certain orientations, etc.) must be innate, the detail of the migration pattern depends largely on local circumstances, which may differ considerably even inside one nursery

As the season proceeds, temperature and oxygen show increasingly large fluctuations over a tidal cycle. Water temperature increases during daytime particularly at low water, whereas oxygen saturation drops markedly at low water during night-time. In August even strong undersaturation of oxygen at high water during daytime has been reported for the tidal flats of the Balgzand (Tijssen \& van Bennekom 1976). Both high temperatures and low oxygen values are likely to be unfavourable for young plaice, but by the time the extremes occur on the Balgzand, the tidal migration behaviour has nearly completely developed and the fish will escape the worst conditions.

In the German Wadden Sea plaice have been found to suffer under high temperature conditions at low water during the period of the development of the tidal migration in June. At temperatures of over $27^{\circ} \mathrm{C}$, which are nearly lethal (Waede 1954), an exodus was observed, but nevertheless on the next day numerous dead plaice were found (Berghahn 1983). The period of larval immigration starts about 1 mo later in the German Wadden Sea (Berghahn 1983) in March, compared to February in the western Wadden Sea (van der Veer 1985), and the development of an adequate tidal migration might therefore also be delayed.

In some years such unfavourable conditions may 
occur even earlier, in May. In this case the last group of newly settled larvae might have to face extreme conditions on the inner lakes at low water, because they still lack a tidal migration. During the whole range of observation on the Balgzand, from 1973 to 1982 (Kuipers 1977, Zijlstra et al. 1982, van der Veer 1986), dead plaice have been found once (by Kuipers: pers. comm.). In a previous paper it was shown that strong year-classes of plaice arrive and settle relatively late at the end of April (van der Veer 1985). This means that in such years a relatively - and also in absolute numbers - large part of the newly-settled plaice still remains on the tidal flats at low water at the end of May. Lethal environmental conditions at that time, especially at low water, might therefore result in a density-dependent mortality between years. In this view the development of tidal migration may be considered as an escape mechanism from unfavourable abiotic conditions around low water.

Such an escape behaviour would support the 'ebb tide theory' of Enright (1970), which is discussed for plaice by Gibson (1975). In this view the survival of the animals is largely dependent on their ability to avoid retention on the flats during ebb tide. Therefore, the animals need a reliable timing mechanism, which because of the unreliability of environmental stimuliis thought to be provided by the internal rhythm. When temperature and oxygen conditions become more and more pressing, plaice might leave the tidal flats sooner after high water. This is indeed suggested by differences in the time at which $50 \%$ of the migrating part of the population had left the tidal flats at falling water in 1980 (Table 1). During the whole period of sampling

Table 1. Pleuronectes platessa. Time (min) before low water together with $95 \%$ confidence limits, at which $50 \%$ of the migrating part of the 0-group plaice population had left the inner lake and drained tidal flats during falling water at day and night. In parentheses: number of observations (1 per $24 \mathrm{~h}$ sampling). Statistical test: sign test

\begin{tabular}{|c|c|c|c|}
\hline \multicolumn{2}{|c|}{ Inner lake } & \multicolumn{2}{|c|}{ Drained flat } \\
\hline Daytime & Night-time & Daytime & Night-time \\
\hline $\begin{array}{c}68 \pm 35 \\
(8)\end{array}$ & $134 \pm 112$ & $\begin{array}{c}126 \pm 44 \\
(12)\end{array}$ & $\begin{array}{c}175 \pm 73 \\
(12)\end{array}$ \\
\hline \multicolumn{2}{|c|}{$p<0.05$} & \multicolumn{2}{|c|}{$p<0.05$} \\
\hline
\end{tabular}

from February to September, plaice left the tidal flats, both the inner lake and the drained flats, earlier during night-time than during daytime. Plaice remaining in the gullies and channel at high tide have only been observed once during night-time after a very hot day in summer (Kuipers pers. comm.). In conclusion, environ- mental factors seem to modulate the actual migration movements of plaice.

Tidal migration shortens the period available for feeding, since food intake is mainly restricted to the tidal flats at high water (Kuipers 1975b). Furthermore, as the season progresses, this feeding period decreases even more, since plaice leave the tidal flats earlier after high water from May onwards. Nevertheless, it does not seem to affect their growth, since previous work revealed that growth curves of the 0-group plaice population on the Balgzand agreed with maximal growth under optimal laboratory conditions (Zijlstra et al. 1982, van der Veer 1986).

\section{LITERATURE CITED}

Berghahn, R. (1983). Untersuchungen an Plattfischen und Nordseegamelen (Crangon crangon) im Eulitoral des Wattenmeeres nach dem Ubergang zum Bodenleben. Helgoländer Meeresunters. 36: 136-181

Bergman, M., Kuipers, B., Spliethoff, P., Veer, H. van der (1976). Garnalen en krabben als mogelijke predatoren van 0-jarige schol op het Balgzand. Visserij 29: 432-438

Bergman, M. J. N., Spliethoff, P. J., Veer, H. W. van der (1980). De ecologie van 0-groep schol (Pleuronectes platessa L.) op het Balgzand. Deel I: Aantalsverloop, verspreiding en getijdenmigratie. Interne Verslagen Nederlands Instituut voor Onderzoek der Zee, Texel, 1980-9: $1-40$

Bregnballe, F. (1961). Plaice and flounder as consumers of the microscopic bottom fauna. Meddr Kommn Danm. Fisk. -og Havunders. N.S. 3: 133-182

Dapper, R., Veer, H. W. van der (1981). Onderzoek naar de ruimtelijke variatie van de bodemsamenstelling op het Balgzand. Interne Verslagen Nederlands Instituut voor Onderzoek der Zee, Texel, 1981-9: 1-21

Edwards, R., Steele, J. H. (1968). The ecology of 0-group plaice and common dab at Loch Ewe. I. Population and food. J. exp. mar. Biol. Ecol. 2: 215-238

Enright, J. T. (1970). Ecological aspects of endogenous rhythmicitiy. Ann. Rev. Ecol. Syst. 1: 221-238

Gibson, R. N. (1973a). Tidal and circadian activity rhythms in juvenile plaice, Pleuronectes platessa. Mar. Biol. 22: 379-386

Gibson, R. N. (1973b). The intertidal movements and distribution of young fish on a sandy beach with special reference to the plaice (Pleuronectes platessa L.). J. exp. mar. Biol. Ecol. 12: 79-102

Gibson, R. N. (1975). A comparison of field and laboratory activity patterns of juvenile plaice. In: Barnes, $\mathrm{H}$. (ed.) Proc. 9th Europ. mar biol. Symp. Aberdeen University Press, Aberdeen, p. 13-28

Kuipers, B. R. (1973). On the tidal migration of young plaice (Pleuronectes platessa) in the Wadden Sea. Neth. J. Sea Res. 6: 376-388

Kuipers, B. R. (1975a). On the efficiency of a two metre beam trawl in juvenile plaice (Pleuronectes platessa). Neth. J. Sea Res. 9: 69-85

Kuipers, B. R. (1975b). Experiments and field observations on the daily food intake of juvenile plaice Pleuronectes platessa L. In: Barnes, H. (ed.) Proc. 9th Europ. mar. biol. Symp. Aberdeen University Press, Aberdeen, p. 1-12

Kuipers, B. R. (1977). On the ecology of juvenile plaice on a 
tidal flat in the Wadden Sea. Neth. J. Sea Res. 11: 56-91

Lockwood, S. J. (1974). The settlement, distribution and movements of 0 -group plaice (Pleuronectes platessa L.) in Filey Bay, Yorkshire. J. Fish Biol. 6: 465-477

Macer, C. T. (1967). The food web in Red Wharf Bay (North Wales) with particular reference to young plaice (Pleuronectes platessa). Helgoländer wiss. Meeresunters. 15: $560-573$

Riley, J. D., Corlett, J. (1966). The numbers of 0-group plaice in Port Erin Bay 1964-66. Rep. mar. biol. Stn Port Erin 78 : $51-56$

Tijssen, S. B., Bennekom, A. J. van (1976). Lage zuurstof gehaltes in het water op het Balgzand. $\mathrm{H}_{2} \mathrm{O}$ 9: 28-31

Tyler, A. V. (1971). Surges of winter flounder, Pseudopleuronectes americanus, into the intertidal zone. J. Fish. Res. Bd Can. 28: 1727-1732

Veer, H. W. van der (1985). Impact of coelenterate predation on larval plaice Pleuronectes platessa and flounder Platichthys flesus stock in the western Wadden Sea. Mar. Ecol. Prog. Ser. 25: 229-238
Veer, H. W. van der (1986). Immigration, settlement and density-dependent mortality of a larval and early postlarval plaice (Pleuronectes platessa) population in the western Wadden Sea. Mar. Ecol. Prog. Ser. 29: 223-236

Waede, M. (1954). Beobachtungen zur osmotischen, chemischen und thermischen Resistenz der Scholle (Pleuronectes platessa) und Flunder (Pleuronectes flesus). Kieler Meeresforsch. 10: 58-67

Wirjoatmodjo, S., Pitcher, T. J. (1984). Flounders follow the tide to feed: evidence from ultrasonic tracking in an estuагу. Estuar. coast. Shelf Sci. 19: 231-241

Wolff, W J., Mandos, M. A., Sandee, A. J. J. (1981). Tidal migration of plaice and flounder as a feeding strategy. In: Jones, N. J., Wolff, W. J. (ed.) Feeding and survival strategies of estuarine organisms. Plenum Press, New York and London, p. 159-171

Zijlstra, J. J., Dapper, R., Witte, J. IJ. (1982). Settlement, growth and mortality of post-larval plaice (Pleuronectes platessa) in the western Wadden Sea. Neth. J. Sea Res. 15: $250-272$

This article was submitted to the editor; it was accepted for printing on May 5, 1986 